\title{
ENHANCING FEDERAL GOVERNMENT MANDATES TO ENSURE CONTINUITY OF HERITAGE LEGACIES
}

\section{Sarah Aziz and Siti Zuhaili Hasan}

Institute for Environment and Development (LESTARI), Universiti Kebangsaan Malaysia, MALAYSIA

*Corresponding author: saziz@ukm.edu.my

Published online: 29 December 2017

To cite this article: Sarah Aziz and Siti Zuhaili Hasan. 2017. Enhancing federal government mandates to ensure continuity of heritage legacies. Kajian Malaysia 35(Supp.1): 165-183. https://doi.org/10.21315/km2017.35.Supp.1.9

To link to this article: https://doi.org/10.21315/km2017.35.Supp.1.9

\section{ABSTRACT}

The responsibility to ensure a legacy is continued, particularly for cultural and natural heritage, often rests with the government agencies, who are armed with the necessary legislative mandates to safeguard and protect them. Heritage in itself has a complex meaning, from the determination of the subject matter itself, the characterisation of its nature and value, to regulating the interactions that may have positive or negative impacts to it. It transcends guarding an object or subject, and involves the complex human-environment relations to the object or subject, encompassing that which is tangible and intangible. In addition, there are times when both cultural and natural heritage become interlinked resulting in it being categorised as mixed heritage, which requires a different set of approaches that complements the need for both cultural and natural heritage conservation. The question to be addressed revolves on what needs to be safeguarded and how can it be properly contextualised, taking into account the complex nature of heritage conservation and the interactions between those who know, those who have "inherited" and have cared for it, with those who are tasked to safeguard it. In addition, there is a need to look at the roles of those who act as custodians, by exploring what entails from the mandate given, towards enabling a collaborative arrangement, in order to ensure that existing mandates become complementary and mutually supportive. This article looks at the intricate relationship focusing on different Federal government mandate holders of cultural and natural heritage conservation, taking into account the federated system of government in place 
in Malaysia. It briefly discusses a segment of the current Federal government arrangement, and challenges as well the opportunities ahead in Malaysia.

Keywords: mandate, heritage law and regulations, federated system of government, heritage governance, heritage custodians

\section{INTRODUCTION}

The determination of what can be termed as a heritage, and the continuation thereof as a legacy, is a complex matter, particularly where framing mandates are concerned. What should be "handed down" and who is responsible to ensure that it is "passed down", including determining the condition it should be in, the narrative that goes with it, along with the needful to maintain it when it is "passed down", will have to be carefully spelt out.

This article is based on the findings of research conducted on aspects related to Federal statutory mandates pertaining to heritage conservation in Langkawi and Melaka, focusing on the Langkawi UNESCO Global Geopark and Melaka UNESCO World Heritage Site. It briefly highlights the key aspects to be considered when reviewing and framing mandates, taking into account what entails where heritage conservation is concerned and the view on custodianship.

The points for consideration in framing a research problem proposed by Daily and Ehrlich (1999) served as a basis for the research on mandates and heritage conservation in the state of Kedah and Melaka. The lynchpin was that nothing remains within the domain of one discipline, thus a particular subject being studied will need to be looked at from a multifaceted perspective, as noted:

Let's consider first the framing of research problems. Since the Middle Ages, the process of cultural evolution has generated a body of nongenetic information sufficiently vast that no one person could hope to grasp more than a tiny fraction of it. If human beings are going to learn more about how the world works, and better direct their collective understanding to the long-term service of humanity, the world of knowledge must be subdivided somehow. Disciplines therefore are necessary. At the same time, few significant human problems lie within the boundaries of current disciplines...failure to recognise the footprint of such problems on what might be thought of as a multidimensional, multidisciplinary surface could lead at best to silly, naive "answers" and, at worst, to bad policies with serious societal consequences (Daily and Ehrlich, 1999: 277). 
In order to better track the footprint of heritage conservation, it becomes necessary to understand, among others, the interests of multiple parties who hold a stake in it, its type, location, condition, as well as the various disciplines required to ensure it is conserved and passed on to the next generation. This required a rethink, from a legal perspective, of the matters pertaining to responsibility over the subject matter, extending beyond the subject matter per se, looking at the various aspects that influence the shaping of present and future interactions with the subject matter.

Heritage conservation is in itself a broad topic. Take an example of a building that is considered a cultural heritage. From a legal perspective, when assigning the mandate to conserve it, various factors will have to be considered. This includes the location of the building, its size and condition. In addition, there are factors relating to potential impacts from surrounding physical development, not to mention future planned spatial development that will have to be looked at too. Then, there is the matter of land use as well as development control, pollution control, the issue of trespass, criminal damage, access and even building maintenance.

Given the diversity of factors to be considered, this would mean that each mandate assigned over each factor would need to be looked at. Once that profile is completed, then there is a need to see where and how it links. As Malaysia adopts a federated system of government, with the Federal Constitution of Malaysia setting out the remits of legislative and executive powers under the purview of Federal and State governments respectively or concurrently, the jurisdiction over the various aspects that make up heritage conservation becomes multi-faceted, rendering a one size fits all solution moot.

This article will look at mandate from the perspective of it setting "expectations about and specifying the means for relevant implementation of actions" (May, 1993). This includes considerations when framing jurisdiction and control over a scope or subject matter or activity, determination of purpose or target to be achieved, as well as implementation of specific measures to fit specific purposes and meet specific objectives.

\section{UNDERSTANDING THE TERM "HERITAGE"}

Determining what is a heritage is complex. At the outset, there is the determination of the subject matter itself, which can represent a "cultural" legacy or one that is "natural", i.e. representing Earth's unique gem or aesthetics or scientific wonderment, and in some cases, it can be a representation of both, a mix of natural and cultural heritage. This is followed by the characterisation of its nature, value as well as analysis of the narrative that shapes the argument on its importance. Once determination is made, external factors or interactions that may have positive or negative impacts to it will also have to be taken into account. 
There is much written on the theoretical need to ground the mechanics of the interpretation of heritage, the way it is framed, and thereafter the actual context that is applied to it. This article highlights only a few references that flag the need to ensure better "framing" of the subject matter or problem to be addressed.

Lowenthal suggests "...heritage denotes everything we suppose has been handed down to us from the past" (2005: 81), with a note of caution, i.e. "...before nature and antiquity could be treasured, they had first to be recognised as realms apart from the everyday present" (Lowenthal, 2005: 82). He further states that "...nature and antiquities alike were seen as inheritances to be held in trust for future generations..." emphasising the fact that it "must be protected and restored not only out of self-interest but as a sacred obligation to future descendants" (Lowenthal, 2005: 84). He also recognises that though not all heritage is desirable, "it is widely viewed as a precious and irreplaceable resource, essential to personal and collective identity and necessary for self-respect" (2005: 81). This would mean interpretation is key to help ensure what is conserved, protected and transmitted is grounded on a purpose that transcends present interest.

Uzzell (1998) also notes that interpretation of heritage is important, for example for cultural heritage, as it has a crucial role to play in regenerating declining urban, industrial and rural areas through tourism and conservation programmes. However, he then goes on to caution in doing so, "trivialising history and inculcating within the public a reactionary, superficial and romantic view of the past" (Uzzell, 1998: 1) must be avoided. He further questions heritage interpretation, looking at the human-environment interaction, with a line of enquiry on whether "interpretation really sought to challenge our thinking about ecological responsibility and the economic development of society?" or "does it only look backwards to a time when the natural world was supposedly under less of a threat from the influence of humans?" (Uzzell, 1998: 1). This raises the point, as to who gets to decide the actual purpose of interpreting or putting heritage into context, by crafting the narrative that highlights its meaning and importance as well as on the benefit to be gained by those in the present and the future.

Deciding on what is heritage would be easier if there is an accepted definition or interpretation as to what it is, but given how multifaceted it is, setting a universal definition would be difficult. The World Heritage Convention 1972, does not define what is heritage, instead it provides an interpretation of cultural heritage, natural heritage and mixed heritage. In Malaysia, the National Heritage Act 2005 (NHA 2005), also does not define heritage in detail, instead Section 2 states that the term "heritage" imports the generic meaning of a National Heritage, sites, objects and underwater cultural heritage whether listed or not in the Register. The NHA 2005 further provides the term "National Heritage" which means any heritage site, heritage object, underwater cultural heritage or any living person declared as a National Heritage under Section 67 of the Act. This suggests that 
heritage is "subjective" as it would depend on those tasked with determining what it is, to set out the criteria.

If heritage is viewed as a legacy, then there is a need to clearly establish how it has and will define the present, whilst reflecting the uniqueness of that past, which hopefully will serve to inform the future. A legacy, as Lowenthal (2005: 81) suggests, stems from two streams, nature and culture. He further notes that despite humankind having reshaped the elements of nature, it is still viewed as distinct from cultural heritage. He notes that "buildings and engineering works, arts and crafts, languages and traditions" are "created out of nature's raw material" (Lowenthal, 2005: 81-82).

Tengberg et al. also state that "cultural and amenity services, human cultures, knowledge systems, religions, heritage values, social interactions" have been influenced and shaped by the "nature of the ecosystems and ecosystem conditions in which the culture is based" (2012: 14). This suggests that when contextualising heritage, the manner in how it has shaped and has influenced cultural and natural heritage will have to be understood.

With regard to cultural heritage, Jokilehto (2006) notes that there is a need to conduct an in-depth study on documents that proffer interpretations or context as to what constitutes cultural property or cultural heritage. He reiterates Edward Burnett Taylor who in his book Primitive Culture (1871) highlighted that culture is that "complex whole which includes knowledge, belief, art, morals, law, custom, and any other capabilities and habits acquired by man" (Jokilehto, 2005: 4). This makes determining what is cultural heritage even more complex, as it wouldn't be enough to simply pigeonhole different attributes of what is representative of a culture and designate them to be handed down to the next generation, without taking into account the various factors that influenced the narrative in the first place.

The act of interpreting "what is heritage" and thereafter categorising it is rather complex, as there are so many factors to be considered. What is needed is a direction as to who, what and how can heritage be determined, including determining the size, scale and area where it is situated (for that which is tangible) as well as the state or condition it is in.

\section{POINTS FOR CONSIDERATION IN HERITAGE CONSERVATION}

Heritage conservation transcends guarding an object or subject. It involves the complex human-environment interaction to the object or subject, encompassing the interaction between the tangible and intangible aspects of the heritage. This would mean that heritage conservation would require setting out measures that safeguard, protect and preserve the subject matter as well as to set the threshold 
for acceptable risk, including the boundary and prescription for human interaction and use.

The need to protect and conserve both tangible and intangible heritage has stretched the concept of heritage conservation even further, where the intrinsic quality of heritage has to be considered. This includes its aesthetic, historic, scientific and social values (Vecco, 2010: 323), which recognises the building of a cultural identity, bridging the tangible and intangible aspects of heritage.

Heritage conservation measures cannot be developed in isolation of customs and traditions, in particular the customary laws and practices governing it. Steps will have to be taken to identify the existing customary laws and practices that have dictated the norms that "govern" the relationship between the subject and the community that interact with it.

In Malaysia, this would include taking into account customary laws that are binding on specific ethnic communities: for example, native laws that govern the orang asli communities, adat perpatih or adat temenggung that concern the many aspects of life of a Malay community; and native customary laws in Sabah and Sarawak. The customary laws, practices and protocols are central to the identity of specific communities, and cannot be ignored when determining what it is heritage, its value, the narrative that has shaped it, and the means to "pass it on".

Authenticity and maintaining authenticity too, is another factor that requires consideration. Edson (2004) notes that heritage can be a representation of a past that "can be either temporal or metaphorical" (2004: 339-341). He further noted that interventions and adaptation can take place "when social patterns outgrow the practice and institutions of the past" affirming the need for a "new scheme of socio-cultural interaction... expression of adapted heritage can contain multiple or contradictory assertion" (Edson, 2004: 339-341). This subsequently raises the question of who can evaluate and determine, and who gets to adjudicate where there is contradiction.

Tangible and intangible heritage, despite being seemingly distinct, have also begun to converge. This was noted at a UNESCO meeting in 1994:

...the history of art and architecture, archaeology, anthropology and ethnology was no longer concentrated on single monuments in isolation but rather on considering cultural groupings that were complex and multidimensional, which demonstrated in spatial terms the social structures, ways of life, beliefs, systems of knowledge, representations of different past and present cultures in the entire world. Each individual piece of evidence should therefore be considered not in isolation but within its whole context with an understanding of the multiple reciprocal relationship that it had with its physical (i.e. tangible) and non-physical (i.e. intangible) environment (UNESCO, 1994). 
The seemingly distinct features between tangible and intangible cultural heritage and natural heritage cannot be looked at independently now, in particular, natural heritage, which lies fully within human control where determining the value and purpose to conserve is concerned. Munjeri (2004: 18) has also stated that the link between the two is critical, in that intangible heritage has provided the larger framework within which tangible heritage could take its shape and significance.

What has to be addressed, where conservation of both types of heritage is concerned, is the problem of expectation (Lowenthal, 2005: 90). Those mandated will need to address the issue of purpose and expectation, as the legacy that is intended to be transmitted contains the narrative that explains what is represented from the past, and its bearing on how the future will continue to take shape.

In addition, mandate holders will also have to consider what will be the motivation behind the "experience" of a heritage. Conservation measures will have to capture aspects related to interaction and the intended experience. Poria, Reichel and Biran (2006: 173) highlighted this, in that attention should extend beyond the physical attributes of sites, its authenticity or characteristics, looking at the potential connection between the visitor and the site. Risk to heritage is another factor to be looked at when developing conservation measures. Rico (2015: 151) highlighted the need for a discussion on risks, i.e. looking at what will be at risk, and what would be the acceptable standards or levels of risk.

Araoz suggests that the "philosophy of conservation and its resulting doctrinal foundation" which includes the regulatory measures that govern it, "are all fixated on the protection of the material vessels that carry the value" (2011: 59). He also notes that values attributed to a heritage place are not an immutable constant, but evolve in respect of time and space, in response to changes in demographics and technology. A generation, he notes (Araoz, 2011: 59), attributes different generational values, different from previous generations.

Given that values may change from one generation to the next, perhaps heritage can be viewed as a regenerative asset (Strange and Whitney, 2003: 220), a means to shape the future of a place from a development point of view. This would mean heritage conservation would need to consider how to frame the goals for heritage sustainability, where instead of being just a legacy, it can be turned into a development catalyst.

Heritage conservation is intricate, as there is a gamut of considerations to be laid out and addressed. This includes assessing state and condition, setting out goals or objectives to be met based on specific purposes that underlie the justification for action in the first place, and detailing out the appropriate actions to be taken, in particular, by whom, and what method or approach to adopt. As a legacy can straddle both cultural and natural heritage, conservation measures should consider taking into account nature's conservation approaches and methods, such as the 
ecosystem's approach, when addressing conservation aspects of cultural heritage as well. This would mean that a platform bringing together mandates that help bridge both aspects would have to be considered. In a nutshell, who gets to decide what should be done, how it should be done, who should do it, on what time scale and where?

\section{CUSTODIANSHIP}

This article favours the context from which "custodianship" is framed as proposed by de Jesus Jopela (2011: 106), as a term that intersects indigenous knowledge systems, intangible cultural heritage, and community stewardship, that helps describe the way to incorporate traditional approaches with statutory mandates. This is read in context with the definition of a custodian provided by the Oxford English Dictionary (2017) that defines it as "a person who has responsibility for taking care or protecting something".

What de Jesus Jopela (2011: 107-108) advocates is that legitimacy of a heritage can draw from historical rights of use and ownership, anchored on age-old traditions, and expressed through the performance of tasks, that may range from administrative, technical to spiritual. He further states, citing different literature, that these kinds of traditional custodianships cannot be transferred, as they are inalienable, intrinsically linked to livelihood of local communities, and are deeply intertwined with heritage.

The point on how to embed traditional custodianship, the intricate web that makes it inseparable between the communities and the heritage, into existing heritage governance measures is not explored here. The hope is that, in the future, existing stewardship and custodianship that is so entrenched in communities who have cusped these treasures for generations, will be incorporated into heritage conservation measures, with partnerships forged between these communities and the government.

The issue that is looked at here revolves on what needs to be safeguarded, what constitutes heritage, and how can it be looked after, taking into account the complex nature of a heritage. In addition, how can measures be instituted to encapsulate interactions between those who hold the legislative mandate with those who know, and have "inherited" and cared for the heritage. What means of arrangement can be postulated to ensure that existing mandates benefit from the support of those who hold custody of the heritage, be it tangible or intangible. 


\section{HERITAGE CONSERVATION: A CHECKLIST}

Heritage conservation, taking into account the points for consideration raised earlier, requires measures that will cusp both natural and cultural heritage as a whole, which does lead to a rather labyrinthine arrangement. It also requires a twopronged approach, conservation as well as development, as the heritage cannot just be frozen in time without adapting to the ever-changing surrounding environment, values and motivation for experience.

In the research on mandates for heritage conservation in Langkawi and Melaka it was noted that it was necessary to breakdown the multiple factors as highlighted herein into sections. This provided the checklist for a review of statutory mandate over those different factors as shown in Table 1, which has been modified from Sarah et al. (2011).

Based on the factors and the review of existing statutory mandates, eight further points of consideration, in formulating a complementary platform to help bring together multiple mandates were identified. These are:

1. Features: What would be the identifiable features of a subject matter of heritage? How will it be showcased, and what would be the central message to be transmitted, and to what target audience? This goes beyond description, characterisation and categorisation, as it will have to encapsulate the essence of the heritage being of value to past generation, and its importance to the present generation to want to continue to transmit it to the future generation, who in turn, would to want to keep it as a legacy.

2. Location: The location of the item or subject matter of concerned is key, and land laws will need to be looked at to determine the state of ownership. For natural areas, the conditions of the gazettal would come into play, as they have bearing on the conservation measures of the area.

3. Existence of customary laws, protocols and practices: The idea here is to carefully determine the traditional means of custodianship that is in place. This ensures that what has already been pre-determined is considered, and serves to guide new means and measures that can help continue legacies.

4. Ownership: This applies to both tangible and intangible cultural heritage as well as natural heritage. It was crucial to determine the type of ownership bestowed over the property, item or subject matter, so as to determine whether the government could, if it was privately owned, to impose measures to effect conservation over the privately-owned item or area. This includes aspects relating to inheritance and trusts. 
5. Risks and threats: The need to determine the state and condition of the subject matter is crucial, as it would also allow for the identification of existing and emerging risks and threats to and from the subject matter. Threats can include threats to local economic development and the exclusion of local communities or "traditional custodians" (borrowing from de Jesus Jopela's [2011] contextualisation of traditional custodianship), as well as traditional customary practices, or in the case of natural heritage sites, disruption of ecosystem services and processes.

6. Valuation and assessment: Determining the value of a heritage subject matter would require the consideration of multiple factors, and requires the engagement of multiple persons or entities or communities that have a

Table 1: List of factors used when reviewing statutory requirements for heritage conservation and development

\begin{tabular}{|c|c|c|c|c|c|}
\hline \multicolumn{3}{|c|}{ Types/Components } & \multirow{2}{*}{$\begin{array}{c}\text { Legal } \\
\text { prerequisites }\end{array}$} & \multirow{2}{*}{$\begin{array}{l}\text { Mandates } \\
\text { required } \\
\text { for heritage } \\
\text { conservation }\end{array}$} & \multirow{2}{*}{$\begin{array}{l}\text { Mandates } \\
\text { required } \\
\text { for heritage } \\
\text { development }\end{array}$} \\
\hline $\begin{array}{l}\text { Natural heritag } \\
\text { biologica }\end{array}$ & $\begin{array}{l}\text { Geological \& } \\
\text { diversity }\end{array}$ & Cultural & & & \\
\hline $\begin{array}{l}\text { Natural features } \\
\text { (rocks, } \\
\text { minerals \& } \\
\text { fossils) } \\
\text { Geomorpho- } \\
\text { logical } \\
\text { features } \\
\text { Soil features }\end{array}$ & $\begin{array}{l}\text { Species } \\
\text { Habitats } \\
\text { Ecosystems }\end{array}$ & $\begin{array}{l}\text { Property } \\
\text { Structure } \\
\text { Artefact } \\
\text { Object } \\
\text { Individual } \\
\text { Community } \\
\text { Item } \\
\text { Sites }\end{array}$ & $\begin{array}{l}\text { Mandate } \\
\text { (Responsibility/ } \\
\text { accountability) } \\
\text { Jurisdiction } \\
\text { (Subject matter/ } \\
\text { scope) }\end{array}$ & \multicolumn{2}{|c|}{$\begin{array}{l}\text { Information } \\
\text { Approach } \\
\text { Methods } \\
\text { Techniques } \\
\text { Tools } \\
\text { Programmes } \\
\text { Activities }\end{array}$} \\
\hline $\begin{array}{l}\text { Specimen } \\
\text { Sites } \\
\text { Features } \\
\text { Formation }\end{array}$ & \multirow{2}{*}{$\begin{array}{l}\text { Ecological } \\
\text { Services and } \\
\text { Processes } \\
\text { (Terrestrial, } \\
\text { marine and } \\
\text { other aquatic } \\
\text { environment) }\end{array}$} & $\begin{array}{l}\text { Formation } \\
\text { Structure } \\
\text { Monuments } \\
\text { Buildings }\end{array}$ & \multirow[t]{2}{*}{$\begin{array}{l}\text { Compliance/ } \\
\text { enforcement } \\
\text { measures }\end{array}$} & $\begin{array}{l}\text { Characterisation } \\
\text { Classification } \\
\text { Categorisation } \\
\text { Designation }\end{array}$ & $\begin{array}{l}\text { Engagement } \\
\text { Identification } \\
\text { Determination } \\
\text { Investment }\end{array}$ \\
\hline $\begin{array}{l}\text { Dynamic } \\
\text { Processes: } \\
\text { Assemblages } \\
\text { Processes } \\
\text { Systems }\end{array}$ & & $\begin{array}{l}\text { Performance } \\
\text { Dance } \\
\text { Song } \\
\text { Music } \\
\text { Language } \\
\text { Literature } \\
\text { Other forms } \\
\text { of artistic } \\
\text { expression }\end{array}$ & & $\begin{array}{l}\text { Listing } \\
\text { Demonstration } \\
\text { Planning } \\
\text { Protection } \\
\text { In situ \& ex situ } \\
\text { Conservation } \\
\text { Rehabilitation } \\
\text { Evaluation } \\
\text { Assessment } \\
\text { Monitoring } \\
\text { Reporting } \\
\text { Review } \\
\text { Revision } \\
\text { Education } \\
\text { Communication }\end{array}$ & $\begin{array}{l}\text { Evaluation } \\
\text { Assessment } \\
\text { Monitoring } \\
\text { Reporting } \\
\text { Review } \\
\text { Revision } \\
\text { Communication } \\
\text { Regulation \& } \\
\text { Guidelines }\end{array}$ \\
\hline
\end{tabular}


stake in the subject matter. It is recommended that for natural and cultural heritage sites the ecosystems approach be also used, as there are linkages between man and nature and the intrinsic link between the two should also be factored together. Tengberg et al. has flagged this, in that conservation perspectives and heritage planning and management need to be "better incorporated within regular planning processes, rather than operating on their own as isolated phenomena" (2012: 15).

7. Development: How the subject matter is to be transmitted, as something to be appreciated and experienced (in some cases) by present and future generations requires a structured approach when developing it as an item of interest. Where cultural heritage is concerned, Edson notes that much of the fascination on heritage is based on an "institutionalised rationalisation of the past that is relevant to a few people but designed to appeal to many cultural tourists" (2004: 344). This leads to the issue of whether heritage should be developed and viewed as a source of pride or a product, or a mix of "pride, unity, ethnic loyalty and nostalgia" (Edson, 2004: 345).

8. Engagement of multiple custodians: One aspect that was noted in both studies in Langkawi and Melaka, was the issue of engagement of local communities by the authorities. The communities have, in both studies, expressed their concern that as they have a stake in the area or the heritage itself, there isn't an easily accessible channel for a two-way communication.

These points of consideration grounded the main review of what mandates are in existence and what mandates should be "created" or "brought" together to facilitate the achievement of a heritage conservation objective in Langkawi and Melaka. In addition, the actions to be taken as noted above, also helped identify opportunities of "new" approaches to be considered to supplant existing governance mandates and statutory regimes.

\section{HERITAGE "CUSTODIANSHIP" AND MANDATES UNDER FEDERAL LAWS}

The checklist in Table 1 helped with the identification of existing government statutory mandates, and what was noted for both Langkawi and Melaka, the institutional arrangement for heritage conservation involved so many agencies, all armed with specific mandates that fit within the identified aspects required for conservation and development. Malaysia's adoption of a federated system of government, lynchpinned to the Federal Constitution, does in a way create 
a rather interesting if not complex situation. There is a three-tiered system of government, i.e. Federal Government, State Government and a Local Authority having mandates over various aspects within a particular State. As the Federal Constitution of 1957 ("Constitution") is the supreme law of the country, it sets out the remits of legislative and executive jurisdiction applicable in all States. Where heritage conservation is concerned for both cultural and natural heritage including mixed heritage in Langkawi in particular, the legislative remit is subject to Articles 73 to 81 of the Constitution, and for executive remit, Articles 92 to 95 .

The Ninth Schedule of the Constitution sets the legislative remit within the purview of the Federal and State governments, detailing them in the form of lists; Federal and State List respectively, and a Concurrent List that provides for "shared" jurisdiction. The term "heritage" is not specifically mentioned in the Constitution, however "protection of heritage" is listed in a Concurrent List, indicating that both Federal and State Government may legislate over the subject matter, provided there is no conflict between the instruments enacted. Should there be conflict between the instruments, then the Federal law would prevail.

What can also be drawn from the three lists is the fact that there are aspects that can be deemed as part of heritage, such as "treasure troves and antiquities", which falls within State government purview or "culture" that sits in the Concurrent List. It is the listing of heritage protection in the Concurrent List that provides the Federal Government together with the State Government an opportunity to institute measures that can now be read within the context of "protection", stretching the term to allow it to include conservation.

The word "conservation" can be found in the Constitution, in the context of a development plan in Article 92. A provision is made in Article 92 for the Federal Government to publish and put into operation a development plan in one or more areas in one or more States. A "development plan" here means a plan for the development, improvement, or conservation of the natural resources of a development area, the exploitation of such resources, or the increase of means of employment in the area.

This can be read to mean that the Federal Government in pursuit of national interest can proclaim a whole area as a development area, which in this case refers to an area reserved for the purposes of conservation of natural resources as natural heritage within the context of development. However, the legislative remit in respect of components that make up natural resources such as land, forests and rocks, where the Constitution is concerned, falls within the purview of the State Government, guided by their own State Constitution. Wildlife, however, falls in the Concurrent List, and for Peninsular Malaysia, there is a specific statutory instrument that regulates the various aspects related to wildlife. This raises the issue of how can all these different mandates be made complementary. 
Heritage as mentioned earlier (for Langkawi and Melaka) falls under the purview of the National Heritage Act 2005 (NHA 2005). Section 2 of the NHA 2005 interprets a heritage item to mean any National Heritage, heritage site, heritage object or underwater cultural heritage and listed in the Register. This would mean that each heritage item would have to be identified in accordance to the provisions of the NHA 2005 for the specific classification as listed in the Register. Proprietary rights of an object discovered after the coming into effect of the NHA 2005 or undiscovered lying or hidden beneath the surface of any ground or in a river or sea is the absolute property of the Federal Government unless it is discovered on alienated land (privately owned land for example), where compensation will be made to acquire the object (Section 48).

It can then be declared as a National Heritage under Section 67, unless the site, object or underwater cultural heritage is situated on State Land. In this instance, the State Authority will have to be consulted prior to the declaration. If the item does not belong to the Federal or State government, then the owner, custodian or trustee will be notified of the intent, 30 days prior to declaration. For a site, object or underwater cultural heritage or living person to be registered as a National Heritage, Section 67(2) of the NHA 2005, provides that the following considerations will have to be taken into account:

1. The historical importance, association with or relationship to Malaysian history;

2. The good design or aesthetic characteristics;

3. The scientific or technical innovations or achievements;

4. The social or cultural associations;

5. The potential to educate, illustrate or provide further scientific investigation in relation to Malaysian cultural heritage;

6. The importance in exhibiting a richness, diversity or unusual integration of features;

7. The rarity or uniqueness of the natural heritage, tangible or intangible cultural heritage or underwater cultural heritage;

8. The representative nature of a site or object as part of a class or type of a site or object; and

9. Any other matter which is relevant to the determination of cultural heritage significance.

The NHA 2005 makes provisions for the power to safeguard, entrusted to a Commissioner appointed under the Act, which includes the identification, protection, conservation, restoration, renovation, maintenance, documentation and 
revitalisation of historic or traditional matter, artefact, area and their environment (Section 6 and Section 7 of the NHA 2005). In addition, the Commissioner can work with local planning authorities or entities for the purpose of safeguarding, promoting and dealing with any heritage (Section 6).

The power to declare a heritage object, which has cultural significance, lies with the Commissioner (Section 49). The Commissioner is also provided with powers to designate any site, which has natural heritage or cultural heritage significance to be a heritage site (Section 24), including adjacent sites as well to protect and enhance the designated site (Section 25). If the sites are located on alienated lands then the Commissioner can, under Section 38, require the owner or occupier to ensure the care of such sites. The Commissioner will have to notify and work with local planning authorities to ensure planning permissions and development, taking into consideration the advice of the Commissioner and the significance of the heritage site or object (Section 32 and Section 40).

The Commissioner when exercising powers designating a site as a heritage site can further apply provisions for the conservation of the area (Section 45). Such an area can include a buffer zone surrounding the central core, and require the adoption, on consultation with the local council, a conservation management plan (Section 46).

The NHA 2005 makes provision for the proprietary rights, as mentioned earlier (Section 48), and application for registration (Section 50) in a manner to be prescribed by the Commissioner. It does not explicitly state here the means of affirming or confirming an application in relation to authenticity or originality, and the engagement of local or traditional custodians to assist in the process is also not provided for.

Provisions for the management of a cultural heritage object is provided in Section 53 of the NHA 2005, where the Commissioner on behalf of the Federal government can hold custody and possession, and shall be responsible for its safeguard and safekeeping. The Commissioner can also require a person in possession of any heritage object deemed to be of national importance to not sell or dispose it (Section 56).

The NHA 2005 makes mention of the responsibilities of an owner or custodian in Section 59 and Section 60 of the NHA 2005, including the requirement to keep a heritage property in good condition and in a secure place. For intangible cultural heritage, under Section 60, the Commissioner may require an owner or custodian to take all the necessary steps to develop, identify, transmit, cause to be performed and facilitate the research on the intangible cultural heritage according to the guidelines and procedures as may be prescribed. The aforementioned guidelines and procedures, at the time of writing this article, are not readily available on the official government website. 
Although the NHA 2005 makes a distinction between an owner, a custodian and a trustee, it does not spell out in detail who or what can fall within those categories. This raises several issues, including whether indigenous groups or individuals can be called custodians, or what instrument or arrangement of custody would qualify a person as a custodian. As for owners, the presumption is that it would be easier to identify them, as they would have to provide proof indicating ownership. However, the manner in which a proof is deemed acceptable is not detailed in the NHA 2005.

Another point to be considered is the mention of trustees in the NHA 2005. The assumption here is that to be deemed a trustee, there would be a need for proof of a trust being formed. However, the procedures or means to recognise a trust is also not made clear. This is crucial as Section 69 of the NHA 2005 states that any National Heritage, which is owned or possessed by a person other than the Federal Government or the State Government, may remain in the possession of its owner, custodian or trustee. Not knowing who would fall within the ambit of a custodian or trustee, can lead to the problem pertaining to continuity of the heritage legacy. Another potential issue may lie with accountability, e.g. where a trust or custodianship is created to span a specific time frame and purpose and does not complement the provision of the NHA 2005.

Issues of mandate conflict may also arise in relation to underwater cultural heritage (Section 61), where the Commissioner may publish in a gazette an area within which an underwater cultural heritage is situated to be a protected zone. What if there are existing laws in place governing State water bodies and coastal waters, and in as far as waters beyond State purview, in Federal areas? Which law would prevail, if for example permits are given for other purposes, such as removal of resources, would the Commissioner have the power to supersede or override the permission already given under a different law?

Furthermore, the specific provisions on natural heritage conservation seem limited as compared to cultural heritage under the NHA 2005. Would this mean that existing laws, for example, the Forestry Act 1984 would prevail over areas rich with natural heritage? Or would the Wildlife Conservation Act 2010 prevail? What about natural marine heritage areas such as corals or mangrove areas? It would seem that they can be registered as a National Heritage under the NHA 2005, but measures to effect conservation and safeguarding of this heritage would fall within the purview of other mandate holders. The issue would arise then when these areas are adjacent to or buffer cultural heritage sites, would the Commissioner then have the power to exercise the provisions to create conservation areas as they are already protected under another statutory instrument?

There are other statutes that can also inform heritage determination process, such as the Geological Survey Act 1974, which provides the government with the 
mandate to conduct survey and develop an information base of the geology of an area. This can be read to also include heritage identification, assessment and valuation, plus determining heritage value.

Land use and development of the area where there is heritage or the area surrounding is another area of concern. Land matters, in Langkawi and Melaka, falls within the purview of the National Land Code 1965, which provides in cases of natural heritage in Section 40 property to lands within the territories of a State and all minerals and rocks lies with the State Authority (Section 5 interpret this to mean Ruler or Governor), including all matters related to disposal (Section 41 to Section 50). Land above the shoreline is classified into three types (Section 51), i.e. town land, village land and country land, and categories of land use, area set according to agriculture, building and industry, in addition to conditions requiring its use for a particular purpose (Section 52).

Under the National Land Code 1965, the State Authority holds the mandate that gives it the right use or access to alienated land (Section 57) and to reserve any land for public purpose (Section 62). This would be a useful mandate to exercise not only for boundary setting, which the Commissioner under the NHA 2005 will have to seek approval from the State Authority, but also for conservation, educational and demonstration purposes, as well as tourism development. Aspects related to ownership, as discussed earlier will also have to be read in conjunction with powers given to the State Authority under land alienation pursuant to the National Land Code 1965.

Another factor to be considered is the economic development aspects, where specific development trajectories will have to be looked at. Planned and existing physical and socio-economic development will have bearing on the heritage subject matter, and this would lie beyond the purview of the Commissioner under the NHA 2005. Physical planning for land and area development for example, lay within the ambit of the Town and Country Planning Act 1976 (TCPA 1976) and the Local Government Act 1976 (LGA 1976). Risks and threats form part of the components used to establish and delineate environmentally sensitive areas in State and Local Structure Plans under the TCPA 1976. As such, aspects related to addressing risks from a spatial point of view, would be better addressed under the planning and development control provisions under the TCPA 1976.

Another point for consideration is where intangible heritage and in some cases tangible heritage is concerned, for example, the protection of intellectual property rights. Laws such as the Copyright Act 1987 that span literary, musical or artistic works will also have to be looked at, as well as for specific goods that are by reputation or specific characteristics essentially attributable to their geographical origin, particularly handicraft or natural products under the Geographical Indications Act 2000. 
This article only highlights some of the key statutory instruments that have bearing on heritage conservation, but there are other instruments that look specifically at either the subject matter itself, the area it is situated in, the state it is in, the threats or risks associated with it as well as the development potential of the subject matter. The quick run through of the basic checklist of Table 1 reveals that the mandates required for heritage conservation, requires the support and bridging of many different statutory instruments. The paragraphs earlier merely referred to Federal laws, but there are also State enactments that will also have to be looked at and considered, when laying out the mandate tapestry for heritage conservation.

\section{CONCLUSION}

Findings from the research in Langkawi and Melaka have shown that where mandates are concerned it is not as clear-cut and the NHA 2005 does not provide the necessary "umbrella" coverage for heritage conservation, based on the basic checklist of factors to be considered when drawing up on the mandates required and mandate holders available. The NHA 2005 identified four main players where heritage conservation is concerned, owners, trustees, custodians and the Commissioner, but there is a need to expand this to include a roster of those with a stake that can be linked to all aspects of heritage conservation.

Drawing up a tapestry of the available mandates that can be leveraged on to structure a network of power and jurisdiction for heritage conservation is necessary. There is a need to put into place a mechanism to allow the different mandates to "converge" and capitalised on, grounded on the purpose and objective of heritage conservation. What needs to be done is, to clarify and make available a collective approach that brings together different means and measures used to identify, assess, describe, characterise and categorise heritage, and structure the purpose and objective to guide conservation and development of the heritage as a legacy.

There is also a need to set up a consortium of sorts, engaging different stakeholders, be it those with statutory mandates or those who hold an interest as custodians or keepers of traditions or cultures as well as those who own or have physical custody of the heritage subject matter. This would allow for a clearer direction of what should be governed, and what mandates can be leveraged on to allow for action to be taken, ensure compliance and facilitate enforcement. The continuance of a legacy attach is dependent on how mandates are leveraged and enhanced, shifting from a one authority knows all approach, to a collective of authorities with a suite of complementary mandates, in partnership with all stakeholders. 


\section{REFERENCES}

Aas, C., A. Ladkin and J. Fletcher. 2005. Stakeholder collaboration and heritage management. Annals of Tourism Research 32(1): 28-48. https://doi.org/10.1016/j. annals.2004.04.005.

Araoz, G. F. 2011. Preserving heritage places under a new paradigm. Journal of Cultural Heritage Management and Sustainable Development 1(1): 55-60. https://doi. org/10.1108/20441261111129933.

Blake, J. 2000. On defining the cultural heritage. International and Comparative Law Quarterly 49(1): 61-85. https://doi.org/10.1108/20441261111129933.

Copyright Act. 1987. Kuala Lumpur: Percetakan Nasional Malaysia Berhad.

Daily, G. C. and P. R. Ehrlich. 1999. Managing earth's ecosystems: An interdisciplinary challenge. Ecosystems 2: 277-280. http://www.jstor.org/stable/3659017.

de Jesus Jopela, A. P. 2011. Traditional custodianship: A useful framework for heritage management in SouthernAfrica? Conservation and Management of Archaeological Sites 13(2-3): 103-122. http://dx.doi.org/10.1179/175355211X13179154165908.

Edson, G. 2004. Heritage: Pride or passion, product or service? International Journal of Heritage Studies 10(4): 333-348. http://dx.doi.org/10.1080/1352725042000257 366.

Federal Constitution of Malaysia. 1957. Kuala Lumpur: Percetakan Nasional Malaysia Berhad.

Geological Survey Act. 1974. Kuala Lumpur: Percetakan Nasional Malaysia Berhad.

Geographical Indications Act. 2000. Kuala Lumpur: Percetakan Nasional Malaysia Berhad.

Harvey, D. C. 2001. Heritage pasts and heritage presents: Temporality, meaning and the scope of heritage studies. International Journal of Heritage Studies 7(4): 319338. http://dx.doi.org/10.1080/13581650120105534.

International Council on Monuments and Sites (ICOMOS). 1987. Charter for the conservation of historic towns and urban areas. http://www.icomos.org/en/179articles-en-francais/ressources/chartersand-standards/159-charter-for-theconservation-of-historic-towns-and-urban-areas (accessed 10 April 2017).

Jokilehto, J. 2005. Definition of cultural heritage: References to documents in history. ICCROM Working Group Heritage and Society. http://cif.icomos.org/pdf_docs/ Documents\%20on\%20line/Heritage\%20definitions.pdf. (accessed 10 April 2017).

Jokilehto, J. 2006. World heritage: Defining the outstanding universal value. City and Time 2(2): 1-10. http://ceci-br.org/novo/revista/docs2006/CT-2006-45.pdf (accessed 10 April 2017).

Local Government Act. 1976. Kuala Lumpur: Percetakan Nasional Malaysia Berhad.

Lowenthal, D. 2005. Natural and cultural heritage. International Journal of Heritage Studies 11(1): 81-92. http://dx.doi.org/10.1080/13527250500037088.

May, P. J. 1993. Mandate design and implementation: Enhancing implementation efforts and shaping regulatory styles. Journal of Policy Analysis and Management 12(4): 634-663. http://www.jstor.org/stable/3325344.

Munjeri, D. 2004. Tangible and intangible heritage: From difference to convergence. Museum International 56(1-2): 12-20. https://doi.org/10.1111/j.1350-0775.2004.00453.x. 
National Forestry Act. 1984. Kuala Lumpur: Percetakan Nasional Malaysia Berhad. National Heritage Act. 2005. Kuala Lumpur: Percetakan Nasional Malaysia Berhad. National Land Code. 1965. Kuala Lumpur: Percetakan Nasional Malaysia Berhad.

Oxford English Dictionary. 2017. Online version. https://en.oxforddictionaries.com/ definition/custodian (accessed 20 April 2017).

Poria, Y., A. Reichel and A. Biran. 2006. Heritage site management: Motivations and expectations. Annals of Tourism Research 33(1): 162-178. https://doi. org/10.1016/j.annals.2005.08.001.

Reyers, B., D. J. Roux, R. M. Cowling, A. E. Ginsburg, J. L. Nel and P. O' Farrell. 2010. Conservation planning as a transdisciplinary process. Conservation Biology 24(4): 957-965. https://doi.org/10.1111/j.1523-1739.2010.01497.x.

Rico, T. 2015. Heritage at risk. In Heritage keywords: Rhetoric and redescription in cultural heritage, eds. K. L. Samuels and T. B. Rico, 147-162. Colorado: University Press of Colorado.

Sarah Aziz, Halimaton Saadiah Hashim, Tanot Unjah, Rahimah Abdul Aziz and K. L. Chan Geraldine. 2011. Land use planning statutes for Langkawi Geopark conservation and development. Planning Malaysia: Conservation with development: Showcasing Langkawi Geopark (Special issue): 83-102.

Strange, I. and D. Whitney. 2003. The changing roles and purposes of heritage conservation in the UK. Planning Practice and Research 18(2-3): 219-229. http://dx.doi.org/1 $0.1080 / 0269745032000168278$.

Tengberg, A., S. Fredholm, E. Eliasson, I. Knez, K. Saltzman and O. Wetterberg. 2012. Cultural ecosystem services provided by landscapes: Assessment of heritage values and identity. Ecosystem Services: 14-26. https://doi.org/10.1016/j. ecoser.2012.07.006.

Town and Country Planning Act. 1976. Kuala Lumpur: Percetakan Nasional Malaysia Berhad.

UNESCO World Heritage Centre. 1994. Expert meeting on the 'Global Strategy' and thematic studies for a representative World Heritage List: WHC-94/CONF.003/ INF 6. http://whc.unesco.org/archive/1994/whc-94-conf003-inf6e.pdf (accessed 10 April 2017).

Uzzell, D. L. 1998. Interpreting our heritage: A theoretical interpretation. In Contemporary issues in heritage and environmental interpretation: Problems and prospects, eds. D. L. Uzzell and Ballantyne, 11-25. London: The Stationery Office. http://www. academia.edu/301486/Interpreting_our_heritage_a_theoretical_interpretation. (accessed 13 April 2017).

Vecco, M. 2010. Adefinition of cultural heritage: From the tangible to the intangible. Journal of Cultural Heritage 11: 321-324. https://doi.org/10.1016/j.culher.2010.01.006.

Wildlife Conservation Act. 2010. Kuala Lumpur: Percetakan Nasional Malaysia Berhad.

Winter, T. 2013. Clarifying the critical in critical heritage studies. International Journal of Heritage Studies 19(6): 532-545. http://dx.doi.org/10.1080/13527258.2012.7 20997. 